\title{
Short-term variation of nutritive and metabolic parameters in Temora longicornis females (Crustacea, Copepoda) as a response to diet shift and starvation
}

\author{
Tobias Kreibich • Reinhard Saborowski • \\ Wilhelm Hagen · Barbara Niehoff
}

Received: 16 October 2007 / Revised: 26 February 2008 / Accepted: 26 February 2008 / Published online: 20 March 2008 (C) Springer-Verlag and AWI 2008

\begin{abstract}
Changes in fatty acid patterns, digestive and metabolic enzyme activities and egg production rates (EPR) were studied in the small calanoid copepod Temora longicornis. Female copepods were collected in spring 2005 off Helgoland (North Sea). In the laboratory one group of copepods was fed with the cryptophycean Rhodomonas baltica for a period of 3 days. Another group of copepods was maintained without food. According to the fatty acid patterns, animals from the field were feeding on a more detrital, animal-based and to a minor extent to a diatom-based diet. Under laboratory conditions, females rapidly accumulated fatty acids such as 18:4 (n-3), 18:3 (n-3) and 18:2 (n-6) which are specific of $R$. baltica. Diatom-specific fatty acids such as 16:1 (n-7) were strongly reduced. In fed animals the activities of digestive and metabolic enzymes remained constant and egg production rates were highest on day 2. Starving animals, in contrast, showed significantly reduced faecal pellet production and EPR. Proteolytic enzyme activity decreased rapidly within $24 \mathrm{~h}$ and remained at a low level until the end of the experiment. Citrate synthase decreased continuously as well. T. longicornis rapidly reacts to dietary changes and food depletion.
\end{abstract}

Communicated by H.-D. Franke.

T. Kreibich $(\bowtie) \cdot$ B. Niehoff

Alfred-Wegener Institute for Polar and Marine Research,

Am Alten Hafen 26, 27568 Bremerhaven, Germany

e-mail: Tobias.Kreibich@awi.de

R. Saborowski

Biologische Anstalt Helgoland, Alfred-Wegener Institute for Polar and Marine Research, 27483 Helgoland, Germany

W. Hagen

Marine Zoology (FB 2), University of Bremen,

P.O. Box 330440, 28334 Bremen, Germany
It has limited energy stores and, thus, strongly depends on continuous food supply.

Keywords Temora longicornis - Digestive enzymes · Metabolism $\cdot$ Fatty acids $\cdot$ Starvation

\section{Introduction}

Copepods are abundant and widespread in the ocean plankton where they constitute a major component of the pelagic food web. As adaptation to different environmental conditions and seasonal cycles they developed a variety of life history traits as well as unique physiological properties. These comprise diapausing, resting eggs, high reproduction rates, vertical migration and efficient energy utilization (Kiørboe et al. 1985; Dahms 1995; Mauchline 1998; Castellani and Lucas 2003). The utilization of food and the deposition of energy reserves are the fundamental processes for survival and reproduction. Feeding and digestion, however, depend on various factors including hydrography, food density, the fitness of the feeder and its ability to cope with changing trophic conditions (Mayzaud 1986; Roche-Mayzaud et al. 1991; Kiørboe and Nielsen 1994). Organisms which are capable of accumulating energy reserves, e.g. lipids, are less vulnerable to fluctuations in food availability. They can survive extended periods with little or even without food while mobilizing their lipid stores (Lee 1975; Lee and Barnes 1975; Sargent and Henderson 1986). On the contrary, organisms which are not able to accumulate energy reserves extremely depend on continuous food supply.

The small calanoid copepod Temora longicornis is one of the most abundant species in the North Sea and other regions of the Northeast Atlantic and, thus, of outstanding 
ecological importance (Fransz et al. 1991; Mauchline 1998). It is known as a species with high metabolic rates but low energy reserves (Mayzaud et al. 1992; Evjemo and Olsen 1997; Helland et al. 2003). Since the plankton composition can change rapidly in the North Sea (Kiørboe and Nielsen 1994), T. longicornis strongly depends on the ability to react rapidly to altering trophic conditions. The digestive system is immediately affected by fluctuations in food supply. Potential effects of the dietary composition on the expression of digestive enzymes were discussed in earlier studies but different and partly contradicting conclusions were drawn. Some authors suggested that digestive activity increases with increasing food supply; whereas, others showed that the digestive activity decreases in copepods under surplus of food (Mayzaud and Conover 1975; Hirche 1981; Hassett and Landry 1983; Harris et al. 1986; RocheMayzaud et al. 1991). As a consequence of food supply, copepods may change their metabolic performance in terms of oxygen consumption or metabolic enzyme activities. Moreover, the reproductive success can change significantly, e.g. egg production rates (EPR) respond within 1 day to dietary changes (Kiørboe et al. 1985; Jónasdóttir and Kiørboe 1996; Hirche et al. 1997).

This study aimed at complementing knowledge on adaptive responses of $T$. longicornis to changing nutritional conditions on different physiological levels. Therefore, we carried out short-term feeding and starving experiments. One group of female $T$. longicornis was incubated over 3 days with the cryptophycean Rhodomonas baltica, a high-quality food for copepods (Klein Breteler 1980; Jónasdóttir 1994; Jónasdóttir and Kiørboe 1996; Koski et al. 1998; Tang et al. 2001; Klein Breteler et al. 2004). Another group of females remained unfed for 3 days. The parameters we selected covered different physiological levels. From daily samples we analysed the changes in the activities of digestive and metabolic enzymes and in EPR; whereas, changes in fatty acid patterns were investigated at the end of the experiments after 3 days of incubation.

\section{Materials and methods}

\section{Origin of samples}

Temora longicornis specimens were sampled in spring (April and May 2005) off Helgoland $\left(54^{\circ} 11^{\prime} \mathrm{N}, 07^{\circ} 54^{\prime} \mathrm{E}\right)$ with a CalCoFi plankton net (500 $\mu \mathrm{m}$ mesh size). The net was towed for $10 \mathrm{~min}$ at $10 \mathrm{~m}$ depth and at a speed of $0.3 \mathrm{~m} \mathrm{~s}^{-1}$. Immediately after capture the plankton samples were transferred to the laboratories of the Marine Station. For each experiment, a feeding experiment in April and a starving experiment in May, about 450 healthy looking females and 50 males were sorted alive under a stereo-microscope.
Due to low numbers of females in the samples we were unable to start both experiments at the same time. Nine groups of ten females each were shock frozen at $-80^{\circ} \mathrm{C}$ after shortly being rinsed in demineralised water. These samples were used for biochemical analysis (dry mass (DM), lipid content, fatty acid composition, metabolic and digestive enzyme activities) representing the in situ condition of the females. Parallel to the zooplankton sampling in April, water samples were taken with a 101 Niskin bottle in $3 \mathrm{~m}$ depth in order to characterise the potential diet of copepods in the field. Water samples were filtered over a $70 \mu \mathrm{m}$ sieve. Thereafter, triplicates of $500 \mathrm{ml}$ were gently filtered over dried GF/C filters $(0.2 \mu \mathrm{m})$. The filters were stored at $-80^{\circ} \mathrm{C}$ until analysis of the fatty acid composition.

\section{Algae culturing}

Rhodomonas baltica (Cryptophycea) was grown in $\mathrm{f} / 2$ medium (Guillard 1975) over several weeks under continuous illumination and aeration. Each day the bottles with the cultures were gently shaken to maintain cells in suspension. Cell concentrations were measured with a cell counter and analyser system $\left(\mathrm{CASY}^{\circledR}\right.$ Model TTC, Schärfe System $\mathrm{GmbH}$ ). At the beginning of the feeding experiment a defined volume of the cultures were filtered on dried GF/C filters and stored at $-80^{\circ} \mathrm{C}$ for subsequent fatty acid analysis.

\section{Experiments}

Both feeding and starving experiments were carried out with healthy looking females and males. For each experiment, about 150 females and 15 males each were placed in three 2.51 beakers containing approximately 21 of algal suspension or filtered sea-water $(0.2 \mu \mathrm{m})$. Males were required for continuous fertilization of females. Copepods were incubated over 3 days. The cell density of $R$. baltica was 20,000 cells ml ${ }^{-1}$. The beakers were kept in the dark at approximately $5^{\circ} \mathrm{C}$ throughout the experiment. The temperature was the same as the ambient water temperature. On day 2 approximately half of the incubation water was exchanged by new medium.

Every day approximately 90 females in total were taken from the beakers. For the measurements of egg and faecal pellet production, 24 females were individually incubated over $24 \mathrm{~h}$ in cell wells $(6.3 \mathrm{ml}$ volume), filled with filtered sea-water $(0.2 \mu \mathrm{m})$, at ambient temperature in a constant temperature room. Every $8 \mathrm{~h}$ eggs and faecal pellets were counted and removed from cell wells in order to avoid cannibalism on eggs and feeding on pellets. The other females were frozen in groups of ten at $-80^{\circ} \mathrm{C}$ for biochemical analysis of digestive and metabolic enzymes. On day 3 additionally three groups of ten females each were taken from the beakers and frozen for the analysis of fatty acids. 
Enzyme analysis

The digestive potential of $T$. longicornis females was represented by total proteolytic activity. As representatives of metabolic activity, citrate synthase (CS, EC 4.1.3.7), the key enzyme of the triacetic acid cycle was selected. All enzymatic assays were carried out in triplicates.

\section{Total proteinase}

Deep-frozen samples (10 individuals) were homogenized in $200 \mu \mathrm{l}$ of ice-cold buffer $\left(0.1 \mathrm{~mol}^{-1} \mathrm{Tris} / \mathrm{HCl} \mathrm{pH} 7\right.$, supplemented with $\left.10 \mathrm{mmol} \mathrm{l}^{-1} \mathrm{CaCl}_{2}\right)$. Proteinase activity was determined with modifications after Saborowski et al. (2004). The copepods were thoroughly squeezed with a micropestle and the extract was centrifuged at $15,000 \mathrm{~g}$ for $10 \min \left(4^{\circ} \mathrm{C}\right)$. Thereafter, the supernatants were transferred into new microtubes and were kept on ice. The total proteinase activity was measured with Azocasein as substrate. Exactly $20 \mu \mathrm{l}$ of the sample ( $20 \mu \mathrm{l}$ of buffer for the control assays) was incubated in microtubes for $5 \mathrm{~min}$ at $30^{\circ} \mathrm{C}$. Then $5 \mu \mathrm{l}$ of azocasein solution (Fluka $11615,1 \%$ in aqua dem.) were added and the tubes were incubated for $1 \mathrm{~h}$ at $30^{\circ} \mathrm{C}$. The reactions were stopped by the addition of $50 \mu \mathrm{l}$ of $8 \%$ trichloroacetic acid (TCA, $8 \%$ in aqua dem.) and cooling on ice. The microtubes were centrifuged at $15,000 \mathrm{~g}$ $\left(4^{\circ} \mathrm{C}\right)$ for $15 \mathrm{~min}$. The optical density of the supernatants was measured at $366 \mathrm{~nm}$.

\section{Citrate synthase}

Deep-frozen samples were homogenized as described above except that $\mathrm{Tris} / \mathrm{HCl}\left(50 \mathrm{mmol}^{-1}, \mathrm{pH} 7\right)$ was used as extraction buffer. CS activity was determined with modifications after Stitt (1984) as described in Saborowski and Buchholz (2002). Exactly $20 \mu$ l DTNB [5,5'-Dithiobis(2nitrobenzoic acid), $6 \mathrm{mmol}^{-1}$ in buffer] (Sigma D8130), $20 \mu \mathrm{l}$ Acetyl-CoA (Acetyl-Coenzyme A tri-lithium salt, $6 \mathrm{mmol}^{-1}$ ) (Roche diagnostics, 10101893001) and $20 \mu \mathrm{l}$ sample were placed in a cuvette and mixed with $520 \mu \mathrm{l}$ of $50 \mathrm{mmol}^{-1}$ Tris/HCl-buffer, $\mathrm{pH} 7.5$ (supplemented with $100 \mathrm{mmol}^{-1} \mathrm{KCl}$ and $1 \mathrm{mmol}^{-1}$ EDTA). After $5 \mathrm{~min}$ of incubation at $30^{\circ} \mathrm{C}, 20 \mu \mathrm{l}$ of oxalacetic acid $\left(12 \mathrm{mmol}^{-1}\right)$ (Sigma O 4126) were added to start the reaction. The increase of absorbance was measured continuously for $180 \mathrm{~s}$ at $405 \mathrm{~nm}$ and at $30^{\circ} \mathrm{C}$.

Dry mass, lipid content and fatty acid analysis

The copepods were lyophilised for $24 \mathrm{~h}$ (Leybold-Heraeus, LYOVAC GT2). The DM was measured with a micro-balance (Sartorius, $\pm 2 \mu \mathrm{g}$ ). The lyophilised samples were then stored at $-80^{\circ} \mathrm{C}$.
Prior to the lipid extraction procedure, organic solvent (dichloromethane:methanol, 2:1/v:v) was added to the copepods $(1.5 \mathrm{ml})$ and to the filter samples $(4 \mathrm{ml})$ and the samples were left for $24 \mathrm{~h}$ at $-80^{\circ} \mathrm{C}$. Thereafter, a defined amount of the internal standard tricosanoic acid (23:0) was added to the samples for the determination of total lipid content. Lipid extraction was performed with minor modifications after Folch et al. (1957) as described by Peters et al. (2006). Sub samples of the total lipid extracts were used for fatty acids analysis after Kattner and Fricke (1986). The fatty acids were first transformed into methyl ester derivates (FAMEs). Then they were separated with a gas chromatograph (HP 6890A) equipped with a DB-FFAP column ( $30 \mathrm{~m}$ length, $0.25 \mathrm{~mm}$ inner diameter and $0.25 \mu \mathrm{m}$ film thickness) operating with a temperature program. Helium was used as carrier gas. Chromatograms were processed and analysed with the software KromaSystem 2000 version 1.83 (Bio-Tek Kontron Instruments). Peaks were identified by means of reference standards and by comparison of relative retention times.

\section{Statistics}

An arc sine square root transformation was performed for statistical operations which require normal distribution of data sets. The Kolmogorov-Smirnov test (with Lilliefors' correction) was used to test data for normality. Variance in homogeneity was tested with the Levene's test. Significant differences between groups were tested either with a Student's $t$ test or a one-way ANOVA followed by the Holm-Sidak post hoc test. The data were analysed with the programme SigmaStat version 3.5 (Systat Software, Inc.).

\section{Results}

Mortality, DM and lipid content of copepods

The mortality was less than $10 \%$ during the entire duration of the experiments. DM and lipid contents of in situ females were not significantly different from females fed with $R$. baltica or starved females ( $t$ tests, $P>0.05$ ) due to high variance. DM were approximately $27 \mu \mathrm{g} \mathrm{ind}^{-1}$ (feeding experiment) and $40 \mu \mathrm{g}$ ind $^{-1}$ (starving experiment). In the feeding experiment, lipid content amounted to $3.4 \pm 0.7 \% \mathrm{DM}$ in in situ females and $3.1 \pm 0.3 \% \mathrm{DM}$ in females fed with $R$. baltica. In the starvation experiments, lipid contents decreased from $6.6 \pm 0.7 \% \mathrm{DM}$ in the animals from the field to $4.7 \pm 1.4 \% \mathrm{DM}$ after 3 days of starvation (Table 1). 
Table 1 Dry mass (DM) $\left(\mu \mathrm{g}\right.$ ind $\left.^{-1}\right)$ and lipid content in $\% \mathrm{DM}$ of in situ females, females fed with $R$. baltica and starved females on day 3 $(\mathrm{n}=3$; mean $\pm \mathrm{SD})$

\begin{tabular}{lcc}
\hline & DM $\left(\mu\right.$ ind $\left.^{-1}\right)$ & Lipid \% DM \\
\hline In situ & $27.6 \pm 6.8$ & $3.4 \pm 0.7$ \\
Fed $R$. baltica $(d 3)$ & $26.4 \pm 9.6$ & $3.1 \pm 0.3$ \\
In situ & $40.5 \pm 2.9$ & $6.6 \pm 0.7$ \\
Starved $(d 3)$ & $39.0 \pm 3.3$ & $4.7 \pm 1.4$ \\
\hline
\end{tabular}

Faecal pellet production and EPR

Females which were incubated immediately after capture produced 23.3 faecal pellets (FP) female ${ }^{-1}$ day $^{-1}$ (Fig. 1). After 1 day of feeding the faecal pellet production rate (FPR) remained at the same level but increased on day 2 (60.6 FP female ${ }^{-1} \mathrm{day}^{-1}$ ). At day 3, it dropped to $29.2 \mathrm{FP}$ female ${ }^{-1}$ day $^{-1}$. FPR in starved females decreased strongly from 10.3 to $2.2 \mathrm{FP}$ female ${ }^{-1} \mathrm{day}^{-1}$ on day 1 and stayed low throughout the experiment, not exceeding 4.2 FP female $^{-1}$ day $^{-1}$ (Fig. 1).

In fed females, EPR increased within 2 days from 17.7 to 41.6 eggs female ${ }^{-1}$ day $^{-1}$ (Fig. 2). On day 3, only 25.6 eggs female ${ }^{-1}$ day $^{-1}$ were produced. The EPR in starved females decreased throughout the experiment from initially 24.6 to 11.1 eggs female ${ }^{-1}$ day $^{-1}$ on day 3 (Fig. 2).

Proteinase activity of copepods

Proteinase activity was $2.0 \pm 0.2 \times 10^{-2} d \mathrm{E}_{366} \mathrm{~min}^{-1}$ ind $^{-1}$ in animals from the field. In fed animals, the activity was slightly reduced after 1 day to $1.4 \pm 0.2 \times 10^{-2} d \mathrm{E}_{366}$ $\mathrm{min}^{-1}$ ind $^{-1}$ (Fig. 3) but increased constantly in the following

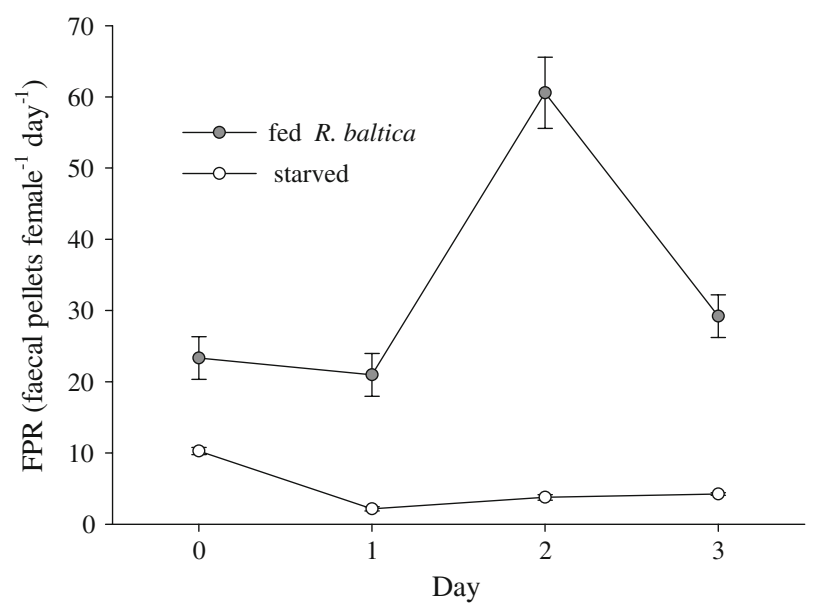

Fig. 1 Faecal pellet production rate (FP female ${ }^{-1} \mathrm{day}^{-1}$ ) of $T$. longicornis females under in situ conditions (day 0 ) and during the experiments incubated with $R$. baltica or under starving conditions $(\mathrm{n}=24$, mean $\pm \mathrm{SD}$ )

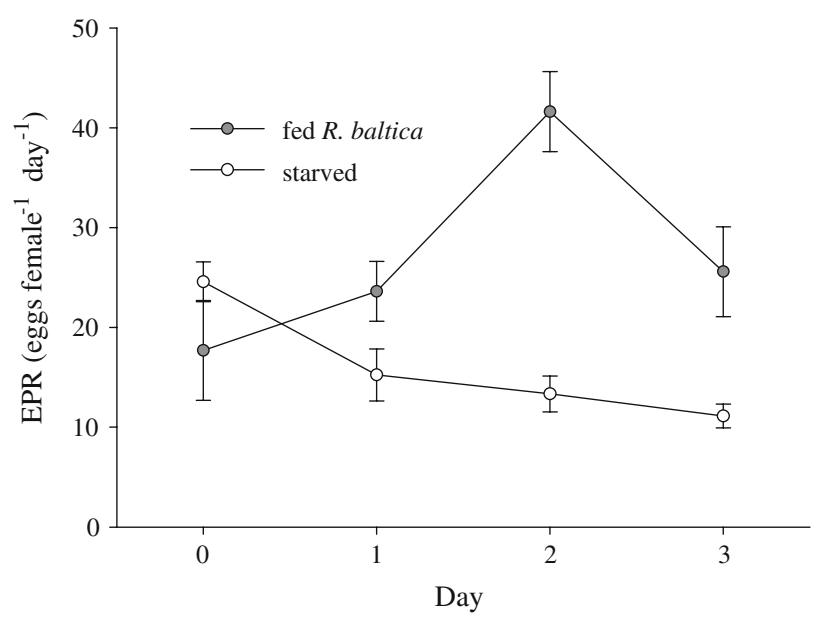

Fig. 2 Egg production rate (EPR, eggs female ${ }^{-1}$ day $\left.^{-1}\right)$ of fed (R. baltica) and starved $T$. longicornis females $(\mathrm{n}=24$, mean $\pm \mathrm{SD})$

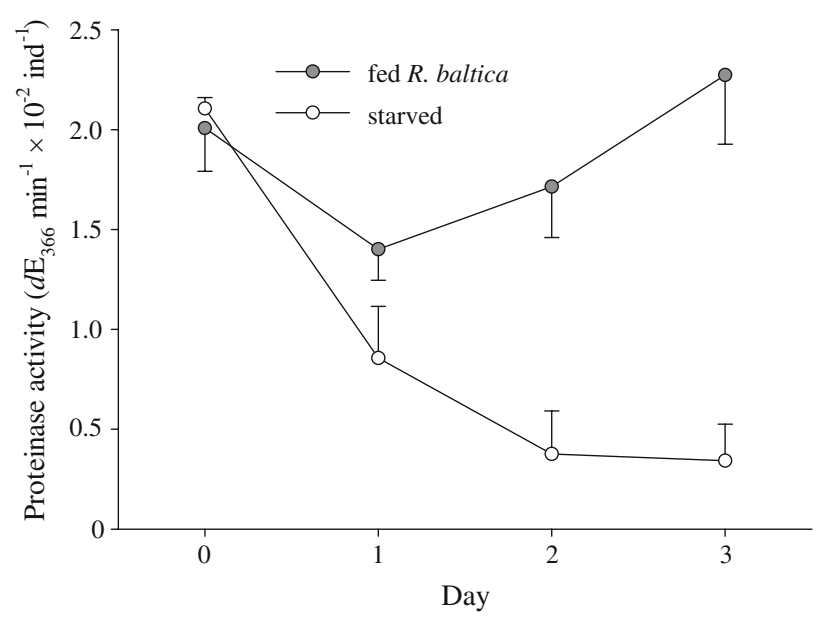

Fig. 3 Proteinase activity $\left(d \mathrm{E}_{366} \min ^{-1} \times 10^{-2}\right.$ ind $\left.^{-1}\right)$ of fed (R. baltica) and starved $T$. longicornis females $(\mathrm{n}=3$, mean $\pm \mathrm{SD})$

days to $2.3 \pm 0.3 \times 10^{-2} d \mathrm{E}_{366} \mathrm{~min}^{-1}$ ind $^{-1}$. Significant differences appeared between day 1 and 3 (one-way ANOVA $P<0.05$, Holm-Sidak post hoc test). In starved animals, proteinase activity decreased constantly from $2.1 \pm 0.1 \times 10^{-2}$ (in situ) to $0.3 \pm 0.2 \times 10^{-2} d \mathrm{E}_{366} \mathrm{~min}^{-1}$ ind $^{-1}$ on day 3 . The reduction was already significant after 1 day under starving conditions (one-way ANOVA $P<0.001$, Holm-Sidak post hoc test).

Citrate synthase

The citrate synthase activity of fed females did not change significantly over time (one-way ANOVA $P>0.05$ ), and ranged between $9.3 \times 10^{-2}$ (in situ) and $8.2 \times 10^{-2} \mathrm{U}$ ind $^{-1}$ (day 3) (Fig. 4). In starved females CS activity decreased constantly during the experiment from $8.5 \times$ $10^{-2}$ to $6.1 \times 10^{-2} \mathrm{U}_{\text {ind }}{ }^{-1}$. The differences between the 


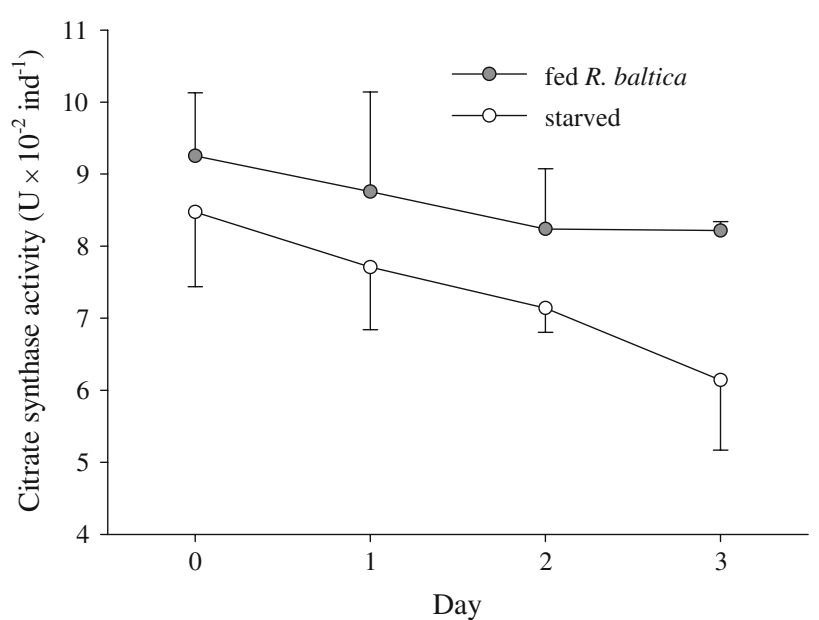

Fig. 4 Citrate synthase activity $\left(\mathrm{U} \times 10^{-2}\right.$ ind $\left.^{-1}\right)$ of fed ( $R$. baltica) and starved $T$. longicornis females $(\mathrm{n}=3$, mean $\pm \mathrm{SD})$

activities of in situ females and starving females were statistically significant on day 3 (one-way ANOVA $P<0.01$, Holm-Sidak post hoc test).

Fatty acid compositions of diets and copepods

The seston and the $R$. baltica culture showed distinct differences in their fatty acid composition. Composition of the seston was characterised by high portions of the saturated fatty acids (SFA) 16:0 [34.0 $\pm 0.5 \%$ of total fatty acids (FA)] and 18:0 (15.3 $\pm 0.5 \%$ FA) (Fig. 5a). The monounsaturated fatty acid (MUFA) 18:1 (n-9) reached 11.4 \pm $0.3 \%$ FA, followed by $16: 1$ (n-7) $(7.8 \pm 0.8 \%$ FA), polyunsaturated fatty acid (PUFA) 20:4 (n-3) (7.6 $\pm 0.4 \%$ FA) and MUFA 18:1 (n-7) $(5.8 \pm 1.2 \%$ FA). In $R$. baltica
(Fig. 5a), major fatty acids were PUFAs 18:4 (n-3) with $28.0 \pm 1.8 \%$ FA, followed by 18:3 (n-3) $(13.3 \pm 1.0 \%)$, $18: 2(\mathrm{n}-6)(11.5 \pm 0.8 \%), 22: 6(\mathrm{n}-3)(9.2 \pm 1.4 \%)$ and MUFA $18: 1(\mathrm{n}-7)$ with $8.3 \pm 0.6 \%$ FA. The SFAs $16: 0$ $(7.0 \pm 2.6 \%$ FA) and 18:0 (1.7 $\pm 1.9 \%$ FA $)$ and MUFA 18:1(n-9) (4.5 $\pm 0.4 \%$ FA) showed relatively low amounts.

The fatty acid pattern of $T$. longicornis changed considerably after 3 days of feeding on $R$. baltica (Fig. $5 \mathrm{~b}$ ). The females from the field showed elevated amounts of the PUFAs 20:5 (n-3) with $29.9 \pm 0.8 \%$ and $22: 6(n-3)$ with $23.5 \pm 2.0 \%$ FA. The SFA 16:0 reached $20.1 \pm 0.9 \%$. After feeding on $R$. baltica, the amount of FA 20:5 (n-3) had decreased significantly to $21.9 \pm 1.1 \%$ ( $t$ test, $P<0.01)$; whereas, FA 22:6 (n-3) increased to $28.2 \pm 1.2 \%$ FA $(t$ test, $P<0.05)$. The FA 16:0 decreased significantly to $13.5 \pm 0.2 \%$ ( $t$ test, $P<0.001$ ). Most distinct changes were observed in the amounts of $18 \mathrm{C}$ fatty acids $(t$ tests, $P<0.01)$. The amount of 18:4 (n-3) increased from $3.4 \pm 0.2$ to $7.8 \pm 0.5 \%, 18: 3$ (n-3) from $0.7 \pm 0.1$ to $4.3 \pm 0.2 \%$, and $18: 2$ (n-6) from $1.2 \pm 0.4$ to $3.9 \pm 0.6 \%$ FA. The MUFA 16:1 (n-7) which reached $3.5 \pm 0.3 \%$ in females from the field, was reduced in fed females to $0.7 \pm 0.1 \%$ FA.

Specific fatty acid accumulation and reduction was calculated as the difference in \% of the amount in situ in \% $\mathrm{DM}$ and the amount in \% DM after 3 days of incubation (Fig. 6). After feeding on $R$. baltica the strongest relative accumulation was observed in 18:3 (n-3) with approximately $430 \%$, followed by $18: 2(\mathrm{n}-6)(153 \%)$ and 18:4 (n-3) (87\%). The strongest decrease was observed in 16:1 (n-7) and 16:3 (n-4), in which both were reduced by approximately $80 \%$ (Fig. 6). The amounts of all fatty acids in starved females were reduced after 3 days of incubation,
Fig. 5 Fatty acid composition (\% of total fatty acids) of seston and $R$. baltica (a) and of T. longicornis in situ and fed with $R$. baltica over 3 days $(\mathbf{b})(\mathrm{n}=3$, mean $\pm \mathrm{SD}$ )
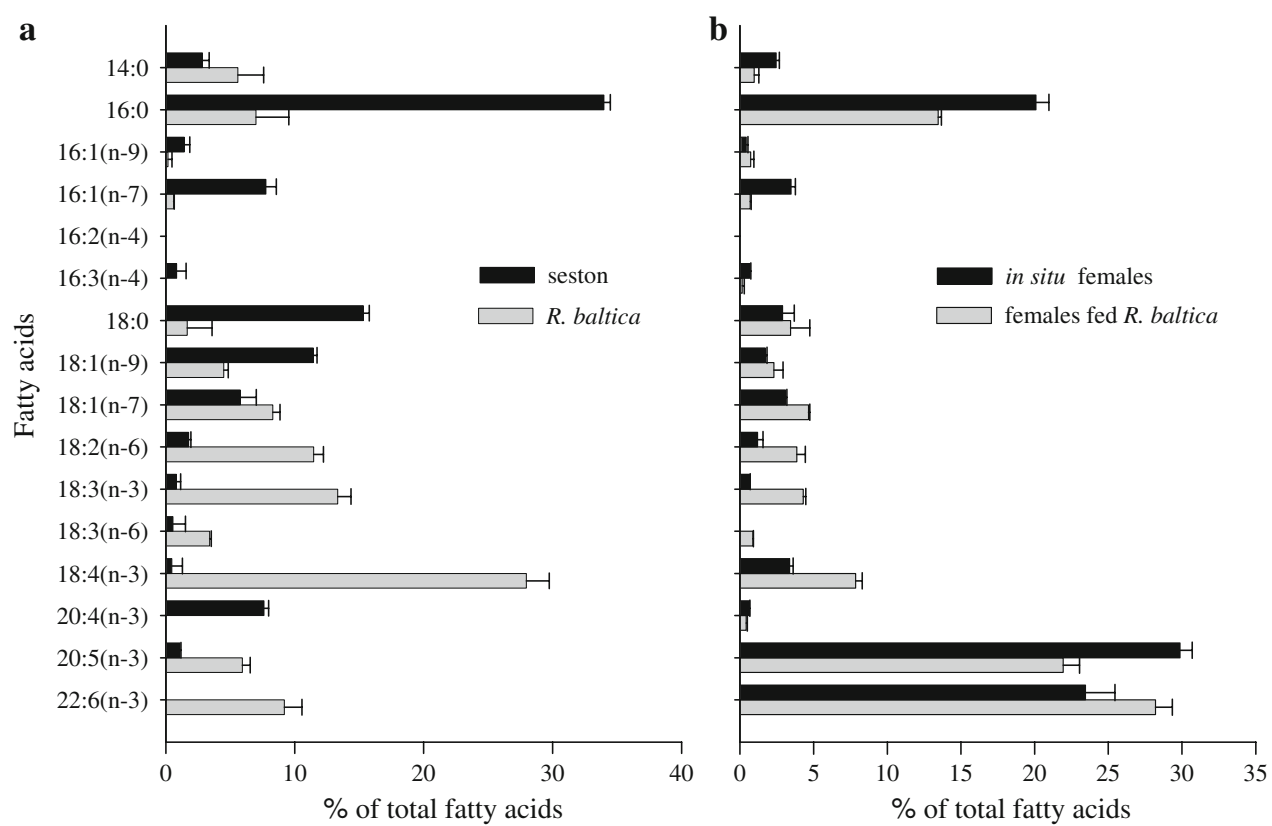


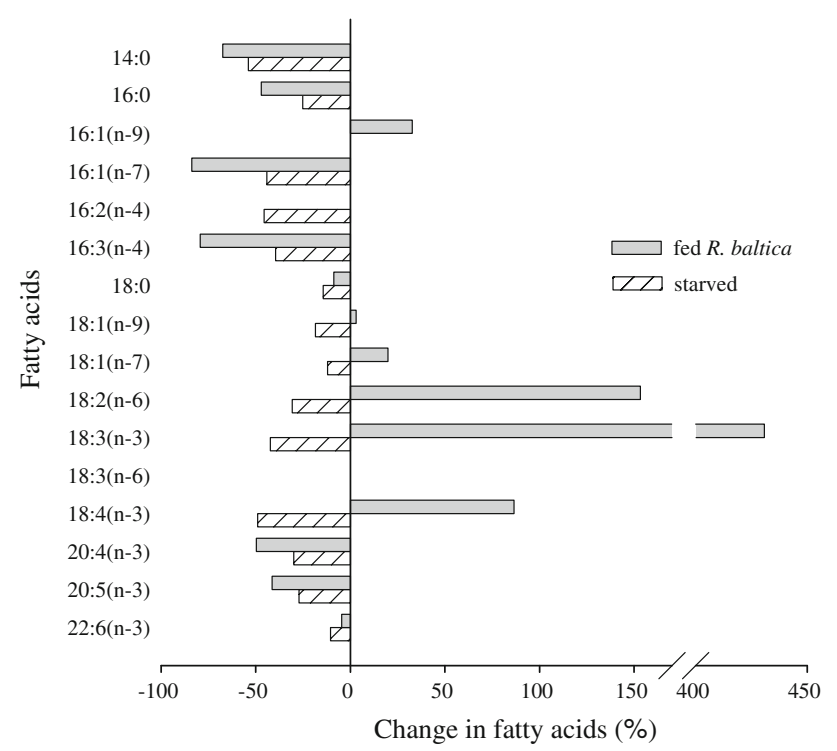

Fig. 6 Changes in amounts of fatty acids of T. longicornis females after 3 days of incubation with $R$. baltica and under starving conditions in \% of in situ amounts (amounts calculated in \% DM)

reduction of single fatty acids ranged between approximately 10 and $54 \%$ of the in situ amount. Strongest reduction were measured for 14:0 (54\%), 18:4 (n-3) (49\%), 16:2 $(\mathrm{n}-4)(46 \%), 16: 1(\mathrm{n}-7)(44 \%)$ and 18:3 (n-3) (42\%).

\section{Discussion}

Temora longicornis showed rapid and distinct physiological responses to changes in diet and to starvation. The dietary shift was reflected by a drastic change in fatty acid patterns; while, starvation caused a significant decrease of digestive proteinase activity, CS activity and EPR. These results complement our view about the trophic interactions and the ecological function of $T$. longicornis in the southern North Sea.

The duration of the experiments ( 3 days) was chosen to exert a significant stress on the animals but to avoid excessive mortality. Indeed, in each of the experiments the mortality of copepods was less than 10\%. Many copepod species show a close correlation between food concentration on one side and ingestion rates and faecal pellet production on the other site (Mauchline 1998, and references therein). The same was true in our experiments for T. longicornis. Feeding on $R$. baltica increased faecal pellet production above in situ rates while starvation drastically reduced faecal pellet production. This is a good confirmation that $T$. longicornis accepted $R$. baltica as food. Moreover, $T$. longicornis continuously increased EPR, showing that food quality was sufficient to maintain physiological integrity and reproductive processes at a high level. In contrast, starving copepods immediately stopped faecal pellet production and continuously reduced the production of eggs.

The shift to Rhodomonas diet did not cause adverse physiological reactions in $T$. longicornis. The average DM as well as the total lipid contents remained at the same level as in the animals from the field. In starving animals; however, the lipid content decreased significantly. T. longicornis does not accumulate high amounts of lipids. In our samples, the lipid values were less than 5\% DM. In contrast, copepod species from high latitudes can accumulate lipids up to $75 \%$ of their DM (Lee et al. 2006). Accordingly, T. longicornis depends on the continuous supply of food and suffers immediately in periods of starvation. A clear indication for starvation is the rapid and almost entire depletion of storage lipids. Merely polar lipids remained in the samples after 3 days. These, however, significantly contribute to structural cell components and, thus, cannot be metabolised without risking cellular integrity (Sargent et al. 1987).

The effects of the dietary composition or starvation on the activities of digestive enzymes of copepods were discussed controversially (Mayzaud and Conover 1975; Hirche 1981; Hassett and Landry 1983). Some authors reported that digestive enzyme activities rise when food concentrations increased while others showed the opposite. In our study, proteinase activities in T. longicornis females remained at the same level between females from the field and those fed with $R$. baltica. In contrast, starving animals lost almost their entire proteolytic activity within 2 days. The reduction of the digestive potential may be seen as an immediate mechanism to save metabolic energy. Upon sufficient food supply the copepods synthesize and release digestive enzymes to efficiently utilize the ingested food. Rapid ingestion and, thus, faster gut passage causes a significant loss of enzymes via the release of faecal pellets (Nott et al. 1985). In order to maintain a high digestive potential the copepods have to keep enzyme synthesis rates high as well. As soon as food supply, ceases, high enzyme synthesis rates are physiologically adverse; their synthesis is metabolically costly and high activities of particularly proteolytic enzymes may cause lesions in the animals. Assuming that $T$. longicornis is capable of increasing digestive enzyme synthesis rates after short periods of hunger as rapid as reducing it, then this reaction appears to be a primary and efficient mechanism for saving metabolic energy without a lasting loss of physiological performance.

Citrate synthase is an important metabolic key enzyme of the tricarboxylic acid cycle. In several studies, alterations in enzyme activity was shown to be related to the nutritional state of the animals (Clarke and Walsh 1993; Meyer et al. 2002). The T. longicornis females in our experiments, which were fed with Rhodomonas, maintained CS 
activities at an almost constant level. Accordingly, it can be suggested that these females maintained metabolic capacities similar to those of animals in the field. In contrast, a strong reduction of particularly CS activity was evident when the animals were starved. These results are in accordance with previous work by Clarke and Walsh (1993) who showed that citrate synthase activity decreased in starving T. longicornis already after $24 \mathrm{~h}$. Apparently, starving $T$. longicornis reduce their capacity for aerobic energy generation due to the lack of both dietary substrates and extensive storage products. The rapid reduction of metabolic rates enables the animals to extend their time of survival and reproduction.

The trophic biomarker concept is based on the observation that specific dietary fatty acids are incorporated largely unmodified into the lipid pool of the consumer (Sargent and Whittle 1981; Sargent et al. 1987; Graeve et al. 1994; Dalsgaard et al. 2003). In calanoid copepods from polar regions they provide trophic information over a time scale of several weeks (Graeve et al. 1994). However, for small calanoid copepods such as $T$. longicornis information about time scales for the incorporation of dietary fatty acids is scarce. We found that the fatty acid composition changed rapidly in $T$. longicornis. The seston in the field contained high amounts of saturated fatty acids (16:0 and 18:0), which are characteristic of detritus (Kattner et al. 1983). Moreover, 18:1 (n-9), which is a major fatty acid in most marine animals (Sargent and Falk-Petersen 1981; FalkPetersen et al. 1990) accounted to about $11 \%$ of total fatty acids in the seston. This indicates that the seston predominantly contained detritus of poor nutritive quality and heterotrophic organisms. On the other hand, Rhodomonas spp. are characterised by the presence of PUFAs with $18 \mathrm{C}$ atoms, such as 18:4 (n-3), 18:3 (n-3) and 18:2 (n-6), and essential fatty acids such as EPA (eicosapentaenoic acid), DHA (docosahexaenoic acid) (Jónasdóttir 1994) and sterols (Klein Breteler et al. 2004). Veloza et al. (2006) showed in feeding experiments with Acartia tonsa that dietary fatty acids are accumulated within 5 days. We observed an accumulation of specific $R$. baltica fatty acids 18:1 (n-7), 18:2 (n-6), 18:3 (n-3) (linolenic acid), 18:3 (n-6), 18:4 (n-3) and 22:6 (n-3) (DHA) already within 3 days. It can be suggested that the dynamics of trophic marker accumulation in T. longicornis may be even more rapid. As an exception the amount of the fatty acid 20:5 (n-3) (EPA) decreased in the copepods although it showed higher values in $R$. baltica than the seston. The seston was pre-filtered over a $70 \mu \mathrm{m}$ sieve. Therefore, larger organisms, which might contain elevated amounts of 20:5 (n-3) and served as food for T. longicornis, might have been excluded from the sample.

Several authors discussed that long chain (n-3) PUFAs are important for growth and development in marine calanoid copepods (Jónasdóttir 1994; Jónasdóttir and Kiørboe
1996). Therefore, the decrease of EPA and, to a lower extent, DHA may indicate that these fatty acids were used for reproductive processes, since egg production rate EPR increased in females fed with $R$. baltica. In feeding experiments with A. tonsa Veloza et al. (2006) suggest that low amounts of EPA in A. tonsa may indicate that EPA is catabolised by the copepod. Jónasdóttir (1994) suggested that Acartia spp. females utilize energy from lipids to fuel biosynthesis of egg-yolk, and that specific dietary fatty acids, probably 20:5 (n-3) and 22:6 (n-3), are straight directed to vitellogenesis. Both fatty acids EPA and DHA are essential to copepods, since metazoans are not able at all or only to a low degree to synthesise these fatty acids de novo by e.g. elongation of linolenic acid (Brett and Müller-Navarra 1997). In our study the portion of EPA decreased in \% FA as well as in \% DM in copepods despite the fact that potential precursors such as 18:3 (n-3) and 18:4 (n-3) reached high amounts in $R$. baltica and were accumulated in $T$. longicornis. Therefore, we suggest that in T. longicornis EPA is the main fatty acid, which is metabolised during periods of elevated EPR.

In conclusion, our results show that $T$. longicornis rapidly reacts to dietary changes and food depletion and, thus, strongly depends on continuous food supply. The species has limited energy stores and can survive only short periods of starvation. Upon starvation a sequence of successive physiological reactions appeared to save metabolic energy. These are a strong decrease in digestive proteases activity, followed by a decrease of metabolic enzyme activity and reduced EPR. A nutritional shift entailed a rapid change in the fatty acid composition, which again reflects the limited compensatory ability of $T$. longicornis. Due to these physiological preconditions it appears consistent that the distributional range of $T$. longicornis comprises predominantly the coastal areas and shallow waters (Krause et al. 1995, and references therein), which are rich in nutrients and, thus, continuously provide sufficient food.

Acknowledgments We are grateful to Benjamin Hansen and Eike Gentsch for their support during the experiment, to Constanze von Waldthausen for help in the laboratory and to Urban Tillmann for providing the algae culture. We would like to thank all colleagues at the Biologische Anstalt Helgoland and the Marine Zoology, University Bremen, for their support and laboratory space during experimental and laboratory procedures, and the crew of the R/V "Aade" for careful sampling procedures. This study was funded by the "Struktur-und Investitionsfond des Präsidenten der Helmholtz-Gemeinschaft (President's Initiative and Networking Fund)", Germany, VH-NG-058.

\section{References}

Brett M, Müller-Navarra D (1997) The role of highly unsaturated fatty acids in aquatic foodweb processes. Freshw Biol 38:483-499

Castellani C, Lucas IAN (2003) Seasonal variation in egg morphology and hatching success in the calanoid copepods Temora longicornis, 
Acartia clausi and Centropages hamatus. J Plankton Res 25:527537

Clarke ME, Walsh PJ (1993) Effect of nutritional status on citrate synthase activity in Acartia tonsa and Temora longicornis. Limnol Oceanogr 38:414-418

Dahms H-U (1995) Dormancy in the Copepoda-an overview. Hydrobiologia 306:199-211

Dalsgaard J, St John M, Kattner G, Müller-Navarra D, Hagen W (2003) Fatty acid trophic markers in the pelagic marine environment: a review. Adv Mar Biol 46:225-340

Evjemo JO, Olsen Y (1997) Lipid and fatty acid content in cultivated live feed organisms compared to marine copepods. Hydrobiologia 358:159-162

Falk-Petersen S, Hopkins CCE, Sargent JR (1990) Trophic relationships in the pelagic arctic food web. In: Barnes M, Gibson RN (eds) Proceedings of the 24th European marine biology symposium, Oban, Argyll, Scotland. University Press, Aberdeen, pp 315-333

Folch J, Lees M, Sloane-Stanley GH (1957) A simple method for the isolation and purification of total lipides from animal tissues. J Biol Chem 226:497-509

Fransz HG, Colebrook JM, Gamble JC, Krause M (1991) The zooplankton of the North Sea. Neth J Sea Res 28:1-52

Graeve M, Kattner G, Hagen W (1994) Diet-induced changes in the fatty acid composition of Arctic herbivorous copepods: experimental evidence of trophic markers. J Exp Mar Biol Ecol 182:97-110

Guillard RRL (1975) Culture of phytoplankton for feeding marine invertebrates. In: Smith WL, Chanley MH (eds) Culture of marine invertebrate animals. Plenum Press, New York, pp 26-60

Harris RP, Samain JF, Moal J, Martin-Jezequel V, Poulet SA (1986) Effects of algal diet on digestive enzyme activity in Calanus helgolandicus. Mar Biol 90:353-361

Hassett RP, Landry MR (1983) Effects of food-level acclimation on digestive enzyme activities and feeding behavior of Calanus pacificus. Mar Biol 75:47-55

Helland S, Terjesen BF, Berg L (2003) Free amino acid and protein content in the planktonic copepod Temora longicornis compared to Artemia franciscana. Aquaculture 215:213-228

Hirche H-J (1981) Digestive enzymes of copepodids and adults of Calanus finmarchicus and C. helgolandicus in relation to particulate matter. Kieler Meeresforsch Sonderh 5:174-185

Hirche H-J, Meyer U, Niehoff B (1997) Egg production of Calanus finmarchicus: effect of temperature, food and season. Mar Biol 127:609-620

Jónasdóttir SH (1994) Effects of food quality on the reproductive success of Acartia tonsa and Acartia hudsonica: laboratory observations. Mar Biol 121:67-81

Jónasdóttir SH, Kiørboe T (1996) Copepod recruitment and food composition: do diatoms affect hatching success? Mar Biol 125:743-750

Kattner G, Fricke HSG (1986) Simple gas-liquid chromatography method for the simultaneous determination of fatty acids and alcohols in wax esters of marine organisms. J Chromatogr 361:263-268

Kattner G, Gercken G, Eberlein K (1983) Development of lipids during a spring plankton bloom in the northern North Sea. Mar Chem 14:149-162

Kiørboe T, Nielsen TG (1994) Regulation of zooplankton biomass and production in a temperate, coastal ecosystem. 1. Copepods. Limnol Oceanogr 39:493-507

Kiørboe T, Møhlenberg F, Hamburger K (1985) Bioenergetics of the planktonic copepod Acartia tonsa: relation between feeding, egg production and respiration, and composition of specific dynamic action. Mar Ecol Prog Ser 26:85-97

Klein Breteler WCM (1980) Continuous breeding of marine pelagic copepods in the presence of heterotrophic dinoflagellates. Mar Ecol Prog Ser 2:229-233
Klein Breteler WCM, Koski M, Rampen S (2004) Role of essential lipids in copepod nutrition: no evidence for trophic upgrading of food quality by a marine ciliate. Mar Ecol Prog Ser 274:199-208

Koski M, Klein Breteler WCM, Schogt N (1998) Effect of food quality on rate of growth and development of the pelagic copepod Pseudocalanus elongatus (Copepoda, Calanoida). Mar Ecol Prog Ser 170:169-187

Krause M, Dippner JW, Beil J (1995) A review of hydrographic controls on the distribution of zooplankton biomass and species in the North Sea with particular reference to a survey conducted in January-March 1987. Prog Oceanogr 35:81-152

Lee RF (1975) Lipids of arctic zooplankton. Comp Biochem Physiol 51B:263-266

Lee RF, Barnes AT (1975) Lipids in the mesopelagic copepod, Gaussia princeps. Wax ester utilization during starvation. Comp Biochem Physiol 52B:265-268

Lee RF, Hagen W, Kattner G (2006) Lipid storage in marine zooplankton. Mar Ecol Prog Ser 307:273-306

Mauchline J (1998) The biology of calanoid copepods. Adv Mar Biol $33: 1-710$

Mayzaud P (1986) Digestive enzymes and their relation to nutrition. In: Corner EDS, O’Hara SCM (eds) The biological chemistry of marine copepods. Clarendon Press, Oxford, pp 165-225

Mayzaud P, Conover RJ (1975) Influence of potential food supply on the activity of digestive enzymes of neritic zooplankton. Proceedings of the 10th European symposium on marine biology vol $2 \mathrm{pp}$ $415-427$

Mayzaud P, Roche-Mayzaud O, Razouls S (1992) Medium term time acclimation of feeding and digestive enzyme activity in marine copepods: influence of food concentration and copepod species. Mar Ecol Prog Ser 89:197-212

Meyer B, Saborowski R, Atkinson A, Buchholz F, Bathmann U (2002) Seasonal differences in citrate synthase and digestive enzyme activity in larval and postlarval Antarctic krill, Euphausia superba. Mar Biol 141:855-862

Nott JA, Corner EDS, Mavin LJ, O'Hara SCM (1985) Cyclical contributions of the digestive epithelium to faecal pellet formation by the copepod Calanus helgolandicus. Mar Biol 89:271-279

Peters J, Renz J, van Beusekom J, Boersma M, Hagen W (2006) Trophodynamics and seasonal cycle of the copepod Pseudocalanus acuspes in the Central Baltic Sea (Bornholm Basin): evidence from lipid composition. Mar Biol 149:1417-1429

Roche-Mayzaud O, Mayzaud P, Biggs DC (1991) Medium-term acclimation of feeding and of digestive and metabolic enzyme activity in the neritic copepod Acartia clausi. I. Evidence from laboratory experiments. Mar Ecol Prog Ser 69:25-40

Saborowski R, Buchholz F (2002) Metabolic properties of Northern krill, Meganyctiphanes norvegica, from different climatic zones. II. Enzyme characteristics and activities. Mar Biol 140:557-565

Saborowski R, Sahling G, Navarette del Toro MA, Walter I, GarcíaCarreño FL (2004) Stability and effects of organic solvents on endopeptidases from the gastric fluid of the marine crab Cancer pagurus. J Mol Catal B 30:109-118

Sargent J, Falk-Petersen S (1981) Ecological investigations on the zooplankton community in Balsfjorden, northern Norway: lipids and fatty acids in Meganyctiphanes norvegica, Thysanoessa raschi and $T$. inermis during mid-winter. Mar Biol 62:131-137

Sargent JR, Henderson RJ (1986) Lipids. In: Corner EDS, O`Hara SCM (eds) The biological chemistry of marine copepods. Clarendon Press, Oxford, pp 59-108

Sargent JR, Whittle KJ (1981) Lipids and hydrocarbons in the marine food web. In: Longhurst AR (ed) Analysis of marine ecosystems. Academic Press, New York, pp 491-533

Sargent JR, Parkes RJ, Mueller-Harvey I, Henderson RJ (1987) Lipid biomarkers in marine ecology. In: Sleigh MA (ed) Microbes in the sea. Ellis Horwood, Chichester, pp 119-138 
Stitt M (1984) Citrate synthase (condensing enzyme). In: Bergmeyer HU (ed) Methods of enzymatic analysis, vol IV. Verlag Chemie, Weinheim, pp 353-358

Tang KW, Jakobsen HH, Visser AW (2001) Phaeocystis globosa (Prymnesiophyceae) and the planktonic food web: feeding, growth, and trophic interactions among grazers. Limnol Oceanogr 46:1860-1870

Veloza A, Chu F-LE, Tang KW (2006) Trophic modification of essential fatty acids by heterotrophic protists and its effects on the fatty acid composition of the copepod Acartia tonsa. Mar Biol 148:779-788 